FIU Law Review

Volume 13

Number 1 Environmental Federalism

Article 11

Summer 2018

\title{
Bad Rules Won't Clean Dirty Pools: The Problem Behind Section 523(A)(16) Policy and the Unnecessary Burden It Places on Debtor HOA Members
}

Austin D. Murray

Follow this and additional works at: https://ecollections.law.fiu.edu/lawreview

Part of the Bankruptcy Law Commons

Online ISSN: 2643-7759

Recommended Citation

Austin D. Murray, Bad Rules Won't Clean Dirty Pools: The Problem Behind Section 523(A)(16) Policy and the Unnecessary Burden It Places on Debtor HOA Members, 13 FIU L. Rev. 161 (2018).

DOI: https://dx.doi.org/10.25148/lawrev.13.1.11

This Student Note is brought to you for free and open access by eCollections. It has been accepted for inclusion in FIU Law Review by an authorized editor of eCollections. For more information, please contact lisdavis@fiu.edu. 


\title{
Bad Rules Won't Clean Dirty Pools: The Problem BEHIND SECTION 523(A)(16) POLICY AND THE UnNecessary Burden It Places on DebTor HOA MEMBERS
}

Austin D. Murray*

\begin{abstract}
"The purpose of [the Bankruptcy Code] has been again and again emphasized ... it gives to the honest but unfortunate debtor who surrenders for distribution the property which he owns at the time of bankruptcy, a new opportunity in life and a clear field for future effort, unhampered by the pressure and discouragement of pre-existing debt."

-Justice Sutherland
\end{abstract}

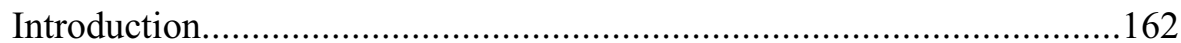

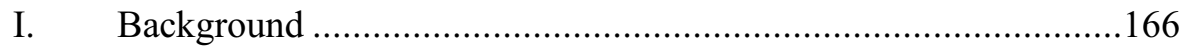

A. History of 11 U.S.C. 523(a)(16) ………..............................166

B. The Reality Facing Vacating Homeowners and the

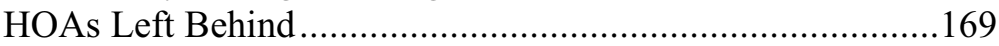

C. The Bankruptcy Courts' Inability to Provide

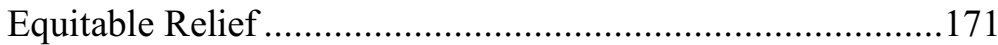

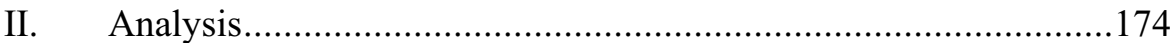

A. Post-petition Assessments are a "Claim" under Section 101(5) of the Bankruptcy Code

B. Bad Rules Don't Clean Dirty Pools: Why Section 523(a)(16) Does Not Actually Protect HOAs.

1. Is lien priority the right solution?....................................180

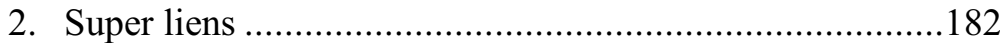

3. HOA foreclosure with junior lien status ...........................183

\footnotetext{
* J.D., 2018, Florida International University College of Law. This Article was written by Mr. Murray while he was a third-year law student and Member of FIU Law Review. Mr. Murray was inspired to write this Article while serving as a Research Assistant for Professor Scott Norberg, during which time he conducted extensive research into the various forms of nondischargeable debt codified in the U.S. Bankruptcy Code. Mr. Murray is a law clerk at Siegfried, Rivera, Hyman, Lerner, De La Torre, Mars \& Sobel, P.A. where he focuses on construction, real estate and community association law. The author wishes to express his gratitude to Professor Scott Norberg, and all of the members of FIU Law for their time, insight, and contribution to this Article.

$\dagger$ Local Loan Co. v. Hunt, 292 U.S. 234, 244 (1934).
} 
4. Changes required in state law to facilitate efficient assessment lien foreclosure..........................................185

C. Justifying an Amendment to Section 523(a)(16) ....................187

D. Proposed Amendment to Section 523(a)(16) .........................188

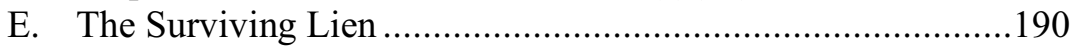

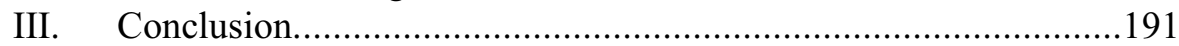

\section{INTRODUCTION}

Although debtors generally seek bankruptcy to obtain a fresh start through the discharge of their pre-petition debts in exchange for their current assets or a portion of their future earnings, Congress has carved out multiple exceptions to this discharge for public policy reasons. ${ }^{1}$ Some exceptions to discharge are due to the debtor's violation of some behavioral standard specified in the Bankruptcy Code. ${ }^{2}$ Other exceptions, such as section 523(a)(16), which is the focus of this Comment, are based solely on the nature of the debt and avoiding potentially harsh repercussions of non-payment to the creditor.

Section 523(a)(16) of the Bankruptcy Code excepts from discharge all post-petition fees or assessments with respect to the debtor's interest in a unit that has condominium ownership, in a share of a cooperative corporations, or a lot in a homeowner's association (collectively "HOAs") for as long as the debtor or the trustee has a legal, equitable, or possessory ownership interest in such a unit. ${ }^{3}$ Although only pre-petition debts are typically dischargeable, HOA fees and assessments present a unique situation where a post-petition debt is the result of a pre-petition agreement between the HOA and the homeowner. Such debts may continue to accrue for months, even years, after the debtor has gone through the bankruptcy proceeding and yearns for a much needed fresh start. ${ }^{4}$ At its inception, section 523(a)(16) excepted from discharge only post-petition HOA fees and assessments while the debtor continued to live on the property or rented out the property. ${ }^{5}$ However, in amending this section in 2005, Congress has significantly increased the burden on the

1 Cara O'Neill, Nondischargeable Debts in Chapter 7 Bankruptcy, NoLO, https://www.nolo.com/legal-encyclopedia/nondischargeable-debts-chapter-7-bankruptcy.html (last visited January 20,2017) (The Bankruptcy Code lists 19 categories of nondischargeable debt. These are debts Congress has determined not dischargeable for public policy reasons based on the nature of the debt or the fact that the debts were incurred due to improper behavior.).

2 Thomas H. Jackson, The Fresh-Start Policy in Bankruptcy, HARV. L. ReV. 1393, 1393 (1985).

3 See 11 U.S.C.A. § 523(a)(16) (West 2017).

4 See Amy Loftsgordon, States With Long Foreclosure Timelines, Nolo, http://www.nolo.com/legal-encyclopedia/states-with-long-foreclosure-timelines.html [hereinafter Loftsgordon, Foreclosure Timelines] (last visited January 20, 2017).

511 U.S.C. § 523(a)(16) (1994). 
debtor to continue paying the fees for as long as the debtor has legal, equitable, or possessory ownership. ${ }^{6}$ Unfortunately for the debtor-member, it is not so easy to shed ownership, especially when the mortgagee is unwilling to foreclose. ${ }^{7}$ However, the 2005 amendment was a victory for HOAs and housing communities who found Congress receptive to their appeals to expand the 1994 exception to discharge. ${ }^{8}$

However, this has not silenced the controversy that has surrounded section 523(a)(16) even from its inception in 1994. For instance, the original provision itself was lobbied against by the National Association of Consumer Bankruptcy Attorneys ("NACBA"), who strongly disapproved of Congress expanding the scope of nondischargeable debts beyond wrongful conduct by the debtor or protection of important governmental interests. ${ }^{9}$ But even this departure from historic bankruptcy law was not enough to satisfy HOA creditors who believed they were entitled to more protection. The main arguments behind this belief were that post-petition assessments are not a claim covered by section 101(5) of the Bankruptcy Code and that HOA fees are a covenant that runs with the land rather than a contractual agreement; ${ }^{10}$ this is all to say that HOA fees and assessments are per se nondischargeable.

Congress has never expressed whether it agrees with either of those arguments, just that it believed HOAs were entitled to more protection as a matter of policy. ${ }^{11}$ Congress certainly considered the importance of HOAs in maintaining the property values within such associations. When HOAs do not receive payment from their homeowners, there is a direct impact on the level of upkeep and maintenance an HOA can afford to put into the common areas that all residents enjoy and that property values are largely based on. More importantly, paying homeowners might be forced to shoulder the loss by either picking up the slack or simply dealing with deteriorating property values while they live in a less desirable community. ${ }^{12}$

611 U.S.C.A $\S 523(\mathrm{a})(16)$ (West 2005).

7 Jeffery S. Adams, Rewriting 11 U.S.C. $\$ 523(A)(16)$ : The Problems of Delayed Foreclosure and Judicial Activism, 30 EMORY BANKR. DEV. J. 347, 349 (2014) (“'With the real estate collapse, lenders, who otherwise have the right to do so, are choosing not to foreclose on their collateral[,] leaving homeowners in limbo.”') (quoting In re Pigg, 453 B.R. 728, 733 (Bankr. M.D. Tenn. 2011)).

8 See In re Pigg, 453 B.R. at 733 (describing $§ 523(a)(16)$ 's expanded coverage as "the result of some special interest lobbying ....").

9 Veryl Victoria Miles, Fairness, Responsibility, and Efficiency in the Bankruptcy Discharge: Are the Commission's Recommendations Enough?, 102 DICK. L. REV. 795, 804 (1998).

10 Alfred Q. Ricotta, Community Associations and Bankruptcy: Why Postpetition Assessments Should not be Dischargeable, 15 EMORY BANKR. DEV. J. 187, 210 (1998).

11 See 140 CONG. REC. S4526 (daily ed. Apr. 20, 1994) (statement of Sen. Strom Thurmond) (noting that association members "may be unfairly burdened by increases in their association fees if their neighbors declare bankruptcy and receive a discharge of the association fees which are due in the future").

12 See id. 
As strong as this policy may be, when one considers the position of the debtor homeowners who surrendered their assets in bankruptcy and are not living on the property or benefitting from it in any way, it is essential to consider if there are alternative mechanisms for protecting the parties involved. Presently, debtor homeowners are not only burdened by post-petition HOA fees and assessments, but are also at the mercy of their lenders who can delay sale of the home for as long as they please. ${ }^{13}$ Therefore, this Comment urges Congress to rethink the necessity of excepting from discharge post-petition HOA fees and assessments when the debtor-member is not living on or benefiting from the property.

Currently, the Bankruptcy Code treats a debtor's right to a fresh start and an HOAs' right to payment as competing interests where one must suffer to protect the other. With the 2005 amendment to section 523(a)(16) Congress tipped the scales in HOAs' favor by keeping the debtor on the hook for HOA fees and assessments until the debtor no longer has any legal, equitable, and possessory interests in the property. ${ }^{14}$

This Comment asserts that Congress overlooked a few important considerations in concluding that the only way to protect HOAs was to have the debtor bear the entire burden. Not only is this an unrealistic way to protect the HOAs' interests, considering the debtor's insolvency, ${ }^{15}$ but it is also an unnecessary deviation from bankruptcy law's "fresh start" policy. ${ }^{16}$ The considerations that Congress overlooked are: (1) the bank has a pecuniary incentive in maintaining the property; ${ }^{17}$ (2) state laws allow banks to delay foreclosure indefinitely; ${ }^{18}$ and (3) accruing HOA fees against the debtor unintentionally benefits the bank and does not incentivize it to take action. ${ }^{19}$

With these considerations in mind, Congress should recognize the mechanisms available to HOAs to mitigate the impact of an HOA member's bankruptcy proceeding, such as lien foreclosure and rent collection. This would result in a more equitable outcome than having the debtor-member shoulder the entire burden of the accumulating obligation. For example, if Congress were to discharge post-petition HOA assessments when the debtor

13 Brandt H. Stitzer, HOA Fees: A BAPCPA Death-Trap, 70 WASH. \& LEE L. REV. 1395, 1419 (2013); see also Adams, supra note 7, at 357 (stating "the liability could theoretically continue "in perpetuity."').

1411 U.S.C.A. $§ 523(a)(16)$ (West 2005).

15 Stitzer, supra note 13, at 1426 (stating that "lack of member equity has rendered $\S 523(\mathrm{a})(16)$ of little value to associations.").

16 Id.

17 See In re Pigg, 453 B.R. 728, 732 n.5 (Bankr. M.D. Tenn. 2011).

18 Christopher W. Frost, Zombie Titles and Bankruptcy: In re Canning, 33 No. 6 BANKR. L. LETTER 1, 1 (2013) (stating that mortgagees may decide that the risks and costs of foreclosure are not worth the effort)

19 See In re Pigg, 453 B.R. at 732 n.5. 
is not living on the property, HOAs could promptly foreclose on their assessment lien and collect rent on the property until the bank forecloses or possibly redeems the property by paying off the assessment lien. This would result in the HOA receiving payment for its fees and assessments without unduly burdening the debtor-member or the mortgage lender.

Because Congress has not taken an express position as to whether postpetition HOA fees and assessments are a dischargeable claim under section 101(5), courts are still struggling with how to treat the debt. ${ }^{20}$ For example, courts addressing chapter 13 bankruptcy cases, which require looking toward section 1328(b) rather than section 523 to determine which debts are nondishcargeable, are torn as to the dischargeability of post-petition HOA assessments, which are not expressly excepted from discharge within section 1328(b). ${ }^{21}$ Therefore, there are important reasons for Congress to confirm or deny that section 523(a)(16) is essential to excepting HOA assessments from discharge in the typical chapter 7 bankruptcy filing. In other words, Congress should take an express stance on whether post-petition HOA fees and assessments are considered a claim under the Bankruptcy Code. With that said, this Comment will proceed by addressing Congress' implicit view of section 523(a)(16), its purpose, and whether, contrary to popular arguments, postpetition HOA fees and assessments meet the Bankruptcy Code's definition of a claim under section 101(5). ${ }^{22}$

Section I begins with an historical overview, which describes the dissonant judicial backdrop that lead to the introduction of the first version of section 523(a)(16) in 1994. The Background section is divided into three subsections. Subsection A explores the possible and likely influences that guided Congress to its eventual 2005 amendment, which drastically changed who the section 523(a)(16) exception to discharge applies to. Subsection B then explains the impact that 2008's financial crisis had on the real estate market and subsequently on the length of the foreclosure process, and how this has levied a significant burden on debtor homeowners who are considered to

20 See In re Hall, 454 B.R. 230, 238 (Bankr. N.D. Ga. 2011) ("It is just as likely that Congress was implying that post-petition assessments are not really claims at all, and that the amendment was necessary to correct the mischaracterization of post-petition assessments as claims."); see also In re Spencer, 457 B.R. 601 (E.D. Mich. 2011) (holding that a debtor's obligation for condominium assessments on unit that he continued to own postpetition, even after announcing his intent to surrender unit, was obligation which ran with the land and which debtor could not discharge as personal prepetition obligation of debtor). But see In re Hawk, 314 B.R. 312, 316-17 (Bankr. D.N.J. 2004) ("By defining the parameters of when postpetition fees and assessments can and cannot [be] discharged, Congress was implicitly stating that these future assessments are claims.").

21 See 11 U.S.C.A. $\$ 1328$ (a) (West 2005) (defining the scope of Chapter 13 discharge, but declining to incorporate $\S 523(\mathrm{a})(16)$ ); see also In re Hawk, 314 B.R. at 316-17. But see In re Foster, 435 B.R. 650, 659 (B.A.P. 9th Cir. 2010) (doubting that "the omission of $\S 1328(a)$ in $\S 523(a)(16)$ or vice versa evinces a legislative intent" that assessments be dischargeable under $\S 1328(\mathrm{a})$ ).

2211 U.S.C.A. $§ 101(5)$ (West 2017). 
have legal ownership of their property until title completely transfers. Subsection $\mathrm{C}$ then explains why the courts' hands are tied to provide relief to these unfortunate debtors and why congressional action is necessary.

Section II then engages in analysis beginning with subsection A, which addresses whether post-petition HOA fees and assessments should be considered a "claim" under section 101(5) the Bankruptcy Code, as this will determine whether these assessments are dischargeable in the first place. After establishing that post-petition assessments should be considered a claim, subsection B explores how section 523(a)(16) is currently ineffective as to serving its intended purpose of protecting HOAs. This transitions into subsection $\mathrm{C}$ which sets forth a number of mechanisms that an HOA could utilize, provided with consistent legislative support, to better protect itself in the event its property owner(s) are not paying the HOA's assessments.

Ultimately, this Comment proposes an amendment to section 523(a)(16) which seeks to, (1) reinstate the dischargeability of post-petition assessments for homeowners who do not possess the property or collect rents on it, (2) retract unfruitful creditor protection from a bankruptcy code intended to provide a fresh start, and (3) better incentivize lenders to contribute to property maintenance costs when they plan to delay foreclosure.

\section{BACKGROUND}

\section{A. History of 11 U.S.C. 523(a)(16)}

Added to the Bankruptcy Code in 1994, Congress enacted section 523(a)(16) to "resolve the split of authority ... regarding the dischargeability of post-petition assessments." ${ }^{\text {"23 }}$ The split consisted of three main lines of authority: (1) post-petition assessments were not dischargeable because they are post-petition obligations that arise from a covenant that runs with ownership of the land, ${ }^{24}$ (2) post-petition assessments were dischargeable as part of a prepetition contract, $^{25}$ and (3) that post-petition assessments were

23 Adams, supra note 7, at 347.

24 In re Rosenfeld, 23 F.3d 833, 837 (4th Cir. 1994) ("Under the Declaration, the obligation to pay assessments is a function of owning the land with which the covenant runs. Thus, Rosenfeld's obligation to pay the assessments arose from his continued post-petition ownership of the property and not from a pre-petition contractual obligation.”).

${ }^{23}$ In re Rosteck, 899 F.2d 694, 696 (7th Cir. 1990) ("It is true that the Rostecks did not actually owe money to Old Willow for assessments beyond those Old Willow had assessed before their bankruptcy. But the condominium declaration is a contract, and by entering that contract the Rostecks agreed to pay Old Willow any assessments it might levy.”). 
dischargeable only if the debtor does not reside in or lease the unit. ${ }^{26}$ Appearing to have adopted the third line of reasoning but not necessarily ruling out the second, the 1994 version of the Section read:

(16) for a fee or assessment that becomes due and payable after the order for relief to a membership association with respect to the debtor's interest in a dwelling unit that has condominium ownership or in a share of a cooperative housing corporation, but only if such fee or assessment is payable for a period during which-

(A) the debtor physically occupied a dwelling unit in the condominium or cooperative project; or

(B) the debtor rented the dwelling unit to a tenant and received payments from the tenant for such period, but nothing in this paragraph shall except from discharge the debt of a debtor for a membership association fee or pending or subsequent bankruptcy case. ${ }^{27}$

Senator Strom Thurmon shed light on what Congress sought to protect by stating that association members "may be unfairly burdened by increases in their association fees if their neighbors declare bankruptcy and receive a discharge of the association fees which are due in the future." ${ }^{28}$ However, it is evident that Congress intended to enforce these fees only against freeriding members who continued to live on their property and receive all the benefits of ownership without paying their fair share of association fees. This is evidenced by the fact that assessments were still dischargeable against the debtors who no longer resided on the property or received rent from it. ${ }^{29}$ This supports the belief that Congress did not intend to address whether HOA fees and assessments are a dischargeable post-petition debt, but rather implemented this Section purely as a matter of public policy. ${ }^{30}$

However, HOAs were discontent with the scope of section 523(a)(16). For one, the 1994 version only afforded protection from the freeriding members of condominiums and cooperatives but omitted homeowner associations. Furthermore, HOAs did not agree with the "you stay, you pay"31 policy

26 In re Ryan, 100 B.R. 411, 416 (Bankr. N.D. Ill. 1989) (“[F]or the post-petition assessments to be discharged, the debtor must ... relinquish possession and other incidents of ownership of the unit in clear and unequivocal terms.”).

2711 U.S.C. $\S 523(\mathrm{a})(16)(1994)$.

28140 CONG. REC. S4526 (daily ed. Apr. 20, 1994) (statement of Sen. Strom Thurmond) (noting that association members "may be unfairly burdened by increases in their association fees if their neighbors declare bankruptcy and receive a discharge of the association fees which are due in the future.").

29 Stitzer, supra note 13 , at 1399.

$30 \quad$ Id. at 1413.

31 Id. at 1415 . 
because it offered no mitigation of harm to associations whose members simply vacated without transferring ownership. ${ }^{32}$

Enter the Bankruptcy Abuse Prevention and Consumer Protection Act of 2005 ("BAPCA"). BAPCA, and its amendments to the prior Code, was an initiative to offer more preference to, and protection for, creditors. ${ }^{33}$ In regard to section 523(a)(16), Congress added homeowner associations to the list of creditors and excepted from discharge all post-petition HOA assessments and fees regardless of whether the debtor occupies the property. This much broader exception reads as follows:

[F]or a fee or assessment that becomes due and payable after the order for relief to a membership association with respect to the debtor's interest in a unit that has condominium ownership, in a share of a cooperative corporation, or a lot in a homeowners association, for as long as the debtor or the trustee has a legal, equitable, or possessory ownership interest in such unit, such corporation, or such lot, but nothing in this paragraph shall except from discharge the debt of a debtor for a membership association fee or assessment for a period arising before entry of the order for relief in a pending or subsequent bankruptcy case. ${ }^{34}$

Essentially, the concern underlying the 2005 amendment was the gap between abandonment of the property by the debtor and the time when the lender or HOA retakes the premises. However, Congress did not foresee lenders delaying foreclosure for an extended length of time. For this reason, the current section 523(a)(16) has come to be known as a "death-trap" for honest debtors seeking a fresh start. ${ }^{35}$ Critics have criticized the faulty assumptions on which the amendment rests, like "vacating debtors [can] easily divest themselves of ownership and escape nondischargeable accruing assessments. ${ }^{36}$ Although some courts conclude that section 523(a)(16)'s language finally "preempts any argument that postpetition fees and assessments should be considered prepetition obligations," 37 the fact that Congress enacted the amendment to serve policy goals without affirming these assertions certainly leaves this question open for debate.

32 Id. at 1417

33 See Donald Hackney, Matthew McPherson, \& Daniel Friesner, Investigating the Unintended Consequences of the 2005 BAPCPA "Means Test" on the Bankruptcy Chapter Choice Decision, 4 J. ECON. BANKING \& FIN. 1, 2 (2011) ("BAPCPA provides a thorough overhaul of the Bankruptcy Code, generally rendering the Code more creditor-friendly.").

3411 U.S.C.A. § 523(a)(16) (West 2005) (emphasis added).

35 Stitzer, supra note 13 , at 1418.

36 Id. at $1418-19$.

37 In re Ames, 447 B.R. 680, 682 n.3 (Bankr. D. Mass. 2011). 


\section{B. The Reality Facing Vacating Homeowners and the HOAs Left Behind}

A few years after the BAPCA amendment to section 523(a)(16), the United States was hit by the 2007-08 real estate market crash. In the wake of the crash, property values slumped so low that lenders frequently decided, "the risk and costs of foreclosures are not worth the effort." ${ }^{38}$ This has lead lenders to categorically deny short sale, auction, and foreclosure requests. ${ }^{39}$ It has also lead to lenders initiating the foreclosure process but not following through, leaving the debtor, the vacated property, and the surrounding community in a state of limbo. ${ }^{40}$ This problem is particularly prevalent in economically distressed areas. A 2010 Government Accountability Office report noted that abandoned foreclosures were concentrated in such areas and "significantly affected those communities by contributing to crime and by depressing the value of the surrounding properties." 41

Almost a decade later, the repercussions of this economic catastrophe are still felt. Before the mortgage crisis, home prices had steadily increased for fifteen years. ${ }^{42}$ In retrospect, it is understandable why Congress amended the section under the assumption that banks would likely choose to foreclose, even if at a small loss, rather than allow the property to sit vacant without bringing in any money. However, due to the staggering plummet in the real estate market, lenders are far more likely to delay the sale of foreclosed property. After all this time, the foreclosure delaying effects of the 2007-08 crash are not only lingering but are on the rise. ${ }^{43}$

Even though data shows that the number of foreclosures is going down, in many states the time it takes to foreclose is increasing. ${ }^{44}$ In the first quarter of 2012 the national foreclosure timeline averaged 370 days, but in the third quarter of 2015 this average had risen to 629 days. ${ }^{45}$ In fact, the foreclosure process has increased year-over-year in twenty-eight states. ${ }^{46}$ According to RealtyTrac (an online marketplace for foreclosure properties and real estate data) the following states are infamously ranked as those with the longest

38 Frost, supra note 18 , at 1.

39 See Better Bankruptcy, SFGATE, http://homeguides.sfgate.com/would-lender-deny-short-salewant-foreclosure-instead-7252.html (last visited March 24, 2017).

40 Frost, supra note 18 , at 1 .

41 Id.

42 Stitzer, supra note 13, at 1419.

43 Loftsgordon, Foreclosure Timelines, supra note 4.

44 Id.

45 Id.

46 Repeat Foreclosure Crisis Starting to Surface?, REALtor MAGAzINE (Nov. 4, 2015), https://magazine.realtor/daily-news/2015/11/04/repeat-foreclosure-crisis-starting-surface. 
foreclosure process: New Jersey (as of the second quarter of 2017, the average foreclosure time in New Jersey is 1,347 days), New York (had the thirdlongest foreclosure timeline, averaging 1,255 days), while Florida foreclosures take around 1,203 days to complete.

With HOA fees typically above $\$ 200$, this could mean a $\$ 6,000$ liability, or more, against a person — or family — with so little to spare. ${ }^{47}$ If Congress had known this would have been the case in 2005, it is not very likely it would have given as much favor to the creditors as it did. This is simply an example of legislation being rationalized upon an assumption that has been proven wrong. Congress likely did not have this scenario in mind three years earlier when it only hoped to better protect creditor rights. In fairness to Congress, Brandt Stitzer did state:

Section 523(a)(16) was likely amended under the assumption that lenders would continue to promptly foreclose on surrendered properties as they had done in the past, or that debtors would continue to have alternative ways to divest themselves of property. The combination of the mortgage crisis and the inability for debtors to divest themselves of their property has proven this assumption defective. ${ }^{48}$

Today, the reality is that transferring ownership is not a fast and easy process, and the debtor has absolutely no control over the timeline. Indeed, there were other factors lengthening the timeline apart from a lender's decision to wait out increased property values, such as the increase of foreclosures that jammed the usual flow of the foreclosure process. ${ }^{49}$ However, the fact that the number of foreclosures is now decreasing, while the time it takes to foreclose is increasing, indicates that lender-delays are currently prolonging the foreclosure process. All the while the debtor is liable for the accruing monthly expenses of maintaining the property. The effects of the lender's leverage and the lack of incentive for the lender to expedite the foreclosure process is harming the debtor. Moreover, the HOA and HOA community are also harmed by these effects as the HOA is better able to recover its assessments and maintain its community when there is a solvent homeowner living on the property rather than an insolvent debtor who has abandoned the property. ${ }^{50}$

47 Loftsgordon, Foreclosure Timelines, supra note 4.

48 Stitzer, supra note 13 , at 1419.

49 In re Spencer, 457 B.R. 601, 612 (E.D. Mich. 2011) ("The confluence of economic forces has flooded the market [with foreclosures] and jammed the usual flow of the foreclosure process, with upstream effects on bankruptcy proceedings.").

50 Stitzer, supra note 13, at 1426 ("The combination of lender delay and lack of member equity has, however, rendered $\S 523(a)(16)$ of little value to associations.”). 
State laws regarding transfer of ownership also place the debtor at a disadvantage. Under the law of many states, perfect title to real estate cannot be abandoned. ${ }^{51}$ This means that while the property is unoccupied the title owner is assumed to continue in possession. ${ }^{52}$ Even in a "title theory" state, where the mortgagee holds the borrower's title to the property as security until all loan payments have been made, the borrower will always be the equitable owner. ${ }^{53}$ Therefore, the obligation to pay HOA fees and assessments would not shift to the mortgagee unless the mortgagee were to take possession. ${ }^{54}$

\section{The Bankruptcy Courts' Inability to Provide Equitable Relief}

So far, the only burdens on the debtor that have been discussed are those that state law imposes. These burdens include permitting mortgagees to delay foreclosure and establishing the debtor as the equitable owner of property they have abandoned even if their lender holds title. However, in addition to these burdens there are little - if any-resources a debtor can turn to for relief. Courtrooms around the nation are at a loss to provide any legally permissible assistance to debtors who find themselves paying HOA fees month after month to benefit a property they have completely disassociated themselves from. ${ }^{55}$

First of all, after the First Circuit's decision in In re Canning, it is unlikely that a debtor could successfully claim that a mortgagee's refusal to foreclose or claim possession of the property violates the bankruptcy code's discharge injunction. The discharge injunction, set out in section 524 of the Bankruptcy Code, "operates as an injunction against ... an act to collect, recover or offset any such [discharged] debt as a personal liability of the debtor." ${ }^{, 56}$ In Canning, the debtor filed under Chapter 7 and received a discharge of the remainder of its mortgage. ${ }^{57}$ The debtor requested that the bank foreclose on the property or otherwise take title to the residence since the

51 Frost, supra note 18, at 4; see, e.g., Town of Sedgwick v. Butler, 722 A.2d 357, 358 (Me. 1998) ("perfect legal title cannot be lost by abandonment . ...").

52 Frost, supra note 18 , at 4.

53 Id. at $4-5$.

$54 \quad I d$. at 5.

55 See In re Beeter, 173 B.R. 108, 113 n. 4 (W.D. Tex. 1994) (finding that factors such as abandonment are not relevant to determining whether post-petition assessments are a dischargeable claim); see also In re Courmier, 434 B.R. 222, 224 (Bankr. D. Mass. 2010) ("At a time when the soaring foreclosure rate has left a backlog of bank-owned properties, and both owners and banks often choose to simply walk away-leaving abandoned homes and buildings to blight and burden their neighborhoods, cities, and towns - the inadequacy of existing state and federal laws to provide meaningful, responsible solutions becomes distressingly obvious. Yet, judges are interpreters and not architects of the law.").

5611 U.S.C.A. § 524(2) (West 2005).

57 In re Canning, 706 F.3d 64, 66 (1st Cir. 2013). 
debtor was still obligated to pay taxes, insurance, and maintenance expenses for the property. ${ }^{58}$ When the bank refused the debtor's request, the debtor filed for a adversary proceeding claiming that the bank was in violation of the discharge injunction and sought an order requiring the bank to either take possession of the property or to deliver unencumbered title to the debtors. ${ }^{59}$

The plaintiff's theory was that the bank was attempting to extract payment of a discharged debt (i.e., the remaining mortgage) by using the debtor's liability as an "equitable owner" as leverage. ${ }^{60}$ In support of this theory the plaintiff relied primarily on In re Pratt. ${ }^{61}$ In Pratt, the same court held that a secured creditor's posture in conditioning release of its lien on full payment of the loan balance amounted to a reaffirmation of debt demand that contravened "the stringent 'anti-coercion' requirements of [the] Bankruptcy Code $\ldots .,{ }^{62}$

However, the First Circuit Court of Appeals noted key distinctions between the facts of Canning and Pratt. First, the court noted the difference in the secured creditors' postures. In Pratt, the secured creditor refused to repossess and conditioned release of its lien upon full payment of the loan balance. ${ }^{63}$ The creditor rested its refusal on its state-law in rem right to enforce its lien against the vehicle even after discharge of Pratt's unsecured liability on the loan. ${ }^{64}$ However, the court reasoned that state law rights are not a defense to violating the discharge injunction if the rights are being asserted to coerce payment of a discharged debt. ${ }^{65}$ By contrast, in Canning, the secured creditor did not require the debtor to pay in full, but rather offered the opportunity for a voluntary settlement or a short sale. ${ }^{66}$ This indicated to the court that the bank had no interest in coercing full payment of the discharged debt and sought to collect no more than the value securing its lien. ${ }^{67}$

Secondly, the court marked the differences in the collateral that the debtors sought to relinquish in the two cases. In Pratt, the property at issue was a car. ${ }^{68}$ This was a critical component of the Pratt holding because unlike real estate, "vehicles rarely appreciate over time." ${ }^{199}$ According to the Bankruptcy

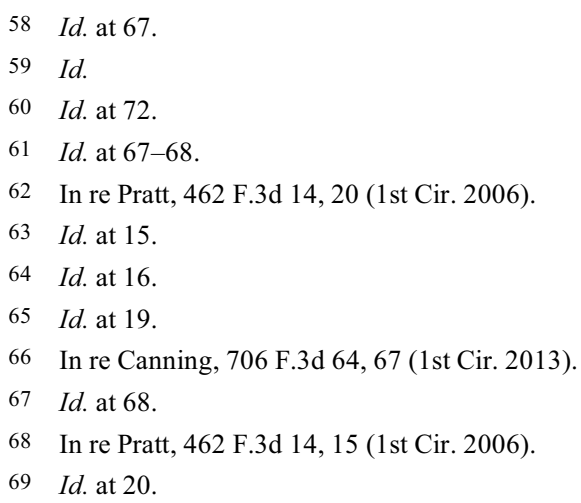


Appellate Panel in Canning as well as the First Circuit Court of Appeals, real estate's ability to increase in value over time provides a compelling reason for creditors to insist on their state law right to retain liens and refuse repossession. ${ }^{70}$ This was not the outcome in Pratt because the car was deemed worthless and the creditor was demanding to be paid in full. ${ }^{71}$

It is unclear if the result in Canning would have been different if the mortgagee had not provided the options of negotiation or short sale to the debtor. However, it is entirely possible that real estate's ability to appreciate in value alone is sufficient to establish that any refusal by a lender to deliver unencumbered title is free of any coercion that would be deemed to violate the discharge injunction. This means that a debtor HOA member who wishes to require its lender to foreclose on the debtor's property in order to relieve the debtor of accruing assessments will not likely have an action against the refusing lender for violation of the discharge injunction.

Furthermore, the Bankruptcy Code itself, despite its fresh start policy, does not offer any clear recourse for a debtor affected by section 523(a)(16). Although debtors have the option under sections 521 and 1325 of the Code to "surrender" their property ${ }^{72}$ judicial interpretation of these provisions hold that a debtor who surrenders is simply agreeing to make the collateral available to the secured creditor and will not oppose transfer of the collateral. ${ }^{73}$ However, in no way does surrendering the property require the creditor to take possession or foreclose on the property. ${ }^{74}$ Moreover, courts do not have the authority to compel acceptance of the surrendered property. ${ }^{75}$ Although many courts have expressed disapproval with the debtor being subject to the lender's will and having no mechanism to avoid accumulating assessments attached to an encumbered property ${ }^{76}$ courts must act as "interpreters and not architects of the law." 77

70 In re Canning, 706 F.3d at 72.

71 In re Pratt, 462 F.3d at 20.

72 See 11 U.S.C.A. $§ 521$ (West 2017); see also 11 U.S.C.A. $§ 1325$ (West 2017).

73 In re Spencer, 457 B.R. 601, 612 (E.D. Mich. 2011).

74 In re Service, 155 B.R. 512, 514 (E.D. Mo. 1993) ("Debtors may not compel this creditor to accept surrender nor enforce its rights and take title to the realty.").

$75 \mathrm{Id}$.

76 See In re Beeter, 173 B.R. 108, 113 n. 4 (W.D. Tex. 1994); see also In re Courmier, 434 B.R. 222, 224 (Bankr. D. Mass. 2010).

77 In re Courmier, 434 B.R. at 224. 


\section{ANAlysis}

A. Post-petition Assessments are a "Claim" under Section 101(5) of the Bankruptcy Code

The Bankruptcy Code section 101(5) defines a "claim" as:

A right to payment, whether or not such right is reduced to judgment, liquidated, unliquidated, fixed, contingent, matured, unmatured, disputed, undisputed, legal, equitable, secured, or unsecured; or

A right to an equitable remedy for breach of performance if such breach gives rise to a right to payment, whether or not such right to an equitable remedy is reduced to judgment, fixed, contingent, matured, unmatured, disputed, undisputed, secured, or unsecured. ${ }^{78}$

Initially, some have argued that post-petition HOA fees and assessments are not prepetition claims within the Code definition of "claim," and therefore, regardless of section 523(a)(16), a debtor cannot discharge such obligations in bankruptcy. ${ }^{79}$ Therefore, the analysis begins with first establishing that post-petition assessments do in fact fit into the Code's definition of "claim" or, at least, that this is what Congress intended.

The primary argument that HOA assessments are not within the Code's meaning of "claim" is that an HOA's right to performance is based on a nondischargeable equitable servitude rather than a contingent right to payment. ${ }^{80}$ In other words, the obligation to pay assessments do not arise from a prepetition contract, but from a covenant running with the land. ${ }^{81}$ This means that the debtor's obligation to the HOA arises from a property interest given by each party, which lasts until legal title is transferred. ${ }^{82}$ The effect of this is that discharging debt tied to property rights would invest a greater property interest in the debtor than it had prior to filing for bankruptcy, which is not the Code's goal. ${ }^{83}$ As one author observes, "The distinction between secured

7811 U.S.C.A. 101(5) (West 2017).

79 Ricotta, supra note 10.

80 Id. at 195.

81 Id. at 188.

82 Stitzer, supra note 13, at 1409.

83 See Cen-Pen Corp. v. Hanson, 58 F.3d 89, 93 (4th Cir. 1995) ("The simple expedient of passing their residence through the bankruptcy estate could not vest in the [debtors] a greater interest in the residence than they enjoyed prior to filing ....") (citing In re Honaker, 4 B.R. 415, 417 (Bankr. E.D. Mich. 1980)). 
claims against debtors' real property and claims against debtors individually, and the ability to separate them, is crucial to this theory." ${ }^{\prime 4}$

The Supreme Court weighed in on this distinction in Johnson v. Home State Bank. This case sets forth the question of whether a debtor, who filed for liquidation under Chapter 7 of the Bankruptcy Code, could be discharged from his mortgage liability ${ }^{85}$ The Court held that a mortgage lien securing an obligation is a "claim" within the meaning of section 101(5) since Congress intended section 101(5) to incorporate the broadest definition of "claim." ${ }^{86}$ Furthermore, the Court stated that "right to payment" means "nothing more nor less than an enforceable obligation."

Notably, the Supreme Court defines a mortgage as an interest in real property that secures creditor's right to payment. ${ }^{88}$ However, the Court did not hold that the complete property right is discharged, just the debtor's obligation under it. ${ }^{89}$ As the Court noted, this leaves the creditor with a surviving right to retain proceeds from the sale or foreclosure of the debtor's property. ${ }^{90}$ The Court states, "[t]hus, a bankruptcy discharge extinguishes only one mode of enforcing a claim - an in personam action - while leaving intact another-an in rem action." ${ }^{91}$ Although this would appear to support the notion that personal rights and property rights arising from HOA assessment obligations are similarly severable, there is still a key distinction between a mortgage and HOA assessments. If an HOA assessment is in fact a covenant that runs with the land, the assessment would be an integral part of the property which became a personal liability when the debtor acquired title to the property. This differs from the in personam liability on a mortgage which is acquired by a debtor as a matter of contract. ${ }^{92}$

Perhaps more indicative of Congress' view on the issue is what Congress believed at the time it made post-petition HOA assessments nondischargeable. Based on congressional commentary and the language of the statute itself, it seems unlikely that Congress takes the stance that assessments accruing after discharge are not otherwise dischargeable. As noted above, Congress indicated that it sought to protect associations from the burden of

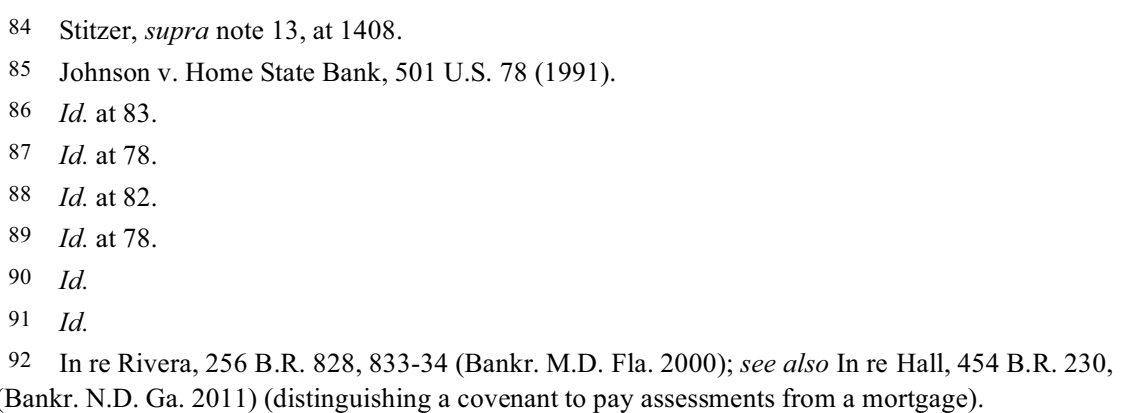
241 (Bankr. N.D. Ga. 2011) (distinguishing a covenant to pay assessments from a mortgage). 
assessment default. ${ }^{93}$ Thus, even in light of the then prevailing argument that these obligations were an integral property right that could not be discharged, Congress focused on the policy reasons for justifying the 2005 amendment and completely ignored the proposition that HOA assessments are covenants that run with the land. This suggests that Congress has considered post-petition HOA assessments to be a right to payment covered by the Code's definition of "claim" all along and that section 523(a)(16) was necessary for Congress to protect HOAs from the discharge of this post-petition debt.

Furthermore, the fact that an HOA assessment may be a covenant running with the land is not dispositive as to whether it creates a right to payment dischargeable under section 101(5). Even if an HOA's right to payment is based on an equitable servitude, it is still may be "a right to payment" contemplated by Congress when it drafted the definition of claim under the Code. The legislative history of section 101(5) indicates that Congress intended "to provide the broadest possible definition of claim." ${ }^{" 94}$ Furthermore, Congress contemplated that "all legal obligations of the debtor, no matter how remote or contingent will be able to be dealt with in the bankruptcy case." 95

Even without this piece of legislative history, the language itself is clear that Congress contemplated equitable rights to payment to be dischargeable. Again, claim is defined as "a right to payment, whether or not such right is ... equitable; or a right to an equitable remedy for breach of performance if such breach gives right to payment." ${ }^{96}$ Nonetheless, critics press forward that HOA fees are not a right to payment, but rather a property interest, based on the equitable servitude theory. ${ }^{97}$ The idea here is that because the debtor's in personam right cannot be separated from the creditor's in rem right without vesting the debtor with a greater property interest, equitable servitudes are per se nondischargeable. However, there is an argument to be made that when an HOA's only interest is in receiving monetary payment then the debtor's obligation to pay that debt is dischargeable. ${ }^{98}$ First, consider the following assertion:

There are several misconceptions about discharging HOA dues that are common among both homeowners and

93140 CONG. REC. S4526 (daily ed. Apr. 20, 1994) (statement of Sen. Strom Thurmond) (noting that association members "may be unfairly burdened by increases in their association fees if their neighbors declare bankruptcy and receive a discharge of the association fees which are due in the future.").

94 Johnson v. Home State Bank, 501 U.S. 78, 83 (1991).

95 S. REP. No. 95-989, at 22 (1978), as reprinted in 1978 U.S.C.C.A.N. 5787, 5808; see also H.R. REP. No. 95-595, at 309 (1978), as reprinted in 1978 U.S.C.C.A.N. 5963, 6266.

9611 U.S.C.A. § 101(5) (West 2017).

97 Ricotta, supra note 10

98 See Ohio v. Kovacs, 469 U.S. 274 (1985) (holding that the bankruptcy code does not require a claim to arise from a contractual arrangement). 
attorneys. It is commonly thought that HOA dues run with land, and are not dischargeable in bankruptcy ... These misunderstandings can be resolved when it is understood that the assessments are not the same thing as the covenants. The Covenants, Conditions, and Restrictions (CC\&Rs) contain a covenant that is a promise to pay the assessments each month they become due. This covenant to pay the assessments is a separate and distinct thing from the actual assessment, which is the dollar amount of fees imposed each month. The covenant in the CC\&Rs runs with the land and can never be removed, but the assessments are regular debts that can be discharged in bankruptcy under a certain set of rules. The truth is that past due HOA arrears are dischargeable in most cases. ${ }^{99}$

Secondly, in Ohio v. Kovacs, the Supreme Court made clear that the bankruptcy code does not require a claim to arise out of a contractual agreement. ${ }^{100}$ In that case, the debtor's obligation arose from a statutory violation, which lead to a court order requiring the debtor to perform environmental cleanup. ${ }^{101}$ However, the Court found that Ohio indicated that it was only interested in "a money payment to effectuate ... cleanup."102 Because the liability was based on a monetary payment, the Court ruled that the right to payment was dischargeable in bankruptcy. ${ }^{103}$ Based on this ruling, it would seem that liability based on a right to monetary payment - even if it arises from a property interest - should be considered a claim in bankruptcy.

This ruling is distinguishable from lower court rulings, which state that just because a debtor has to spend money to comply with a court order does not necessarily create a dischargeable claim. ${ }^{104}$ For example, in Hubler, a district court case affirmed by the Third Circuit, the court addressed the issue of whether an equitable order requiring a party to engage in affirmative acts to clean up the environment gives rise to a "right to payment" that can be considered a claim under the Bankruptcy Code. ${ }^{105}$ The district court's interpretation of Kovacs was that its holding is limited to situations where a

99 Andrew Christensen, Can I Discharge My Home Owner Association Dues in Bankruptcy?, CLINE LAW GRP., https://www.clinelawgroup.com/debts/can-i-discharge-my-home-owner-associationdues-in-bankruptcy/.

100 Kovacs, 469 U.S. at 275.

101 Id. at 276.

$102 I d$. at 281.

103 Id. at 274.

104 See United States v. Hubler, 117 B.R. 160 (W.D. Penn. 1990), aff'd, 928 F.2d 1131 (3rd Cir. 1991).

105 Id. at 163. 
cleanup order is "converted into an obligation to pay money."106 This led the court to hold that equitable court orders, which demand performance and which cannot be satisfied by making a monetary payment, are not dischargeable in bankruptcy. ${ }^{107}$

The Hubler holding does not affect the issue at hand. When it comes to HOA fees and assessments, the sole interest is in monetary payment. Unlike an obligation to perform a task, which may require the ancillary spending of money, HOA assessments create an immediate right to payment where monetary payment is the only way to satisfy the obligation. Therefore, the possibility that an HOA's right to receive payment of its assessment and fees may be based in a property interest is less significant. It is the HOA's "right to payment" that creates a claim under the Bankruptcy Code, not where the right comes from. ${ }^{108}$ This Comment does not overlook the fact that violating a statute, as was the case in Kovacs, does not implicate the same rights as violating a covenant running with the land. However, the overarching opinion of this section is that the actual monetary assessment charged against the debtor is separate from the debtor's promise to pay the assessment each month it becomes due. ${ }^{109}$

Finally, the language of section 523(a)(16) makes clear that Congress views HOA assessments as a "debt." In pertinent part section 523(a)(16) states: "[B]ut nothing in this paragraph shall except from discharge the debt of a debtor for a membership association fee or assessment for a period arising before entry of the order for relief in a pending or subsequent bankruptcy case." ${ }^{110}$ This is significant because the Bankruptcy Code defines "debt" as "liability on a claim," "within the same section of the Code where Congress defines claim. Accordingly, the debt described in section 523(a)(16) is a claim by definition.

Therefore, because (1) the actual assessments are a regular debt that creates a "right to payment"; (2) Congress intended the scope of section 101(5) to be read as broadly as possible; (3) prepetition HOA assessments are dischargeable; and (4) Congress describes HOA assessments as a debt, which by definition makes the assessment a liability based on a claim, it is evident that Congress would recognize that HOA assessments are not a nondischargeable claim in the absence of section 523(a)(16). Thus, the only roadblock to the dischargeability of HOA assessments is section 523(a)(16) itself.

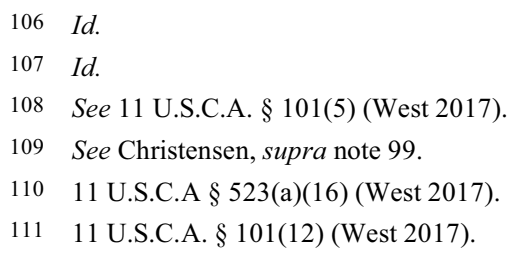


B. Bad Rules Don't Clean Dirty Pools: Why Section 523(a)(16) Does Not Actually Protect HOAs

Because Congress amended section 523(a)(16) in order to protect HOAs rather than to declare HOA assessments per se nondischargeable, it must now be considered whether section 523(a)(16) actually serves its intended purpose. If Congress assumed that the debtor would be able to resort to self-help strategies to pay off the accumulating assessments, it was wrong. As discussed, courts cannot force lender foreclosure and debtors cannot assert violation of the discharge injunction against lenders. ${ }^{12}$ Therefore, an insolvent debtor may have significant difficulty coming up with the means to pay the accruing assessments for an extended period.

A similarly erroneous assumption is that debtors will actually make good on their HOA fees and assessments simply because they are deemed nondischargeable. This is not to say that exceptions to discharge are inherently worthless. However, section 523(a)(16) does present an atypical debt scenario. Unlike many of the prepetition debts excepted from discharge throughout section 523, whether it be for recovery of priority payments or the debtor's bad behavior, section 523(a)(16) refers to an accumulating postpetition debt. ${ }^{113}$ This means that each month will carry with it a new debt balance arising from an interest in property that the debtor-owner does not presently possess. It is not difficult to see why in most cases it is not likely that the insolvent debtor will have the ability or will to pay off each monthly balance pertaining to the abandoned property.

Moreover, depending on state law and the priority provisions in the HOA's Covenants, Conditions, and Restrictions, the HOA may not be entitled to priority payments and may find itself last in a long line of secured creditors. For example, Florida statute Section 720.3085 states that a lien to secure payment of HOA assessments shall relate back to the date on which the original declaration of the community was recorded. ${ }^{114}$ Therefore, as to all creditors besides first mortgagees, a secured interest formed after the HOA recorded its original declaration will be subordinate to the HOA's interest unless federal or state law sets forth otherwise. However, not all states provide such lien status. California law, for example, states that an HOA lien shall be prior to all other liens recorded subsequent to the notice of delinquent assessment. ${ }^{115}$ This means that an HOA lien is subject to the standard priority

112 See In re Canning, 706 F.3d 64, 72 (1st Cir. 2013).

11311 U.S.C.A. § 523(a)(16) (West 2017).

114 FLA. STAT. $§ 720.3085$ (2015).

115 CAL. Civil Code $\S 5680$ (West 2014). 
rule that liens are prioritized by the date they are filed rather than the date the HOA executed its declaration. ${ }^{116}$

Considering the above factors, section 523(a)(16) does not offer necessary protection for the HOA as much as it creates a nuisance for the debtor homeowner. In reality, section 523(a)(16) is more of a windfall for HOAs than a necessary provision to ensure recovery of default assessments. Any well counseled HOA would know that, in most circumstances, engaging in time consuming litigation against an insolvent debtor is far less efficient than placing a lien on the property and foreclosing on it. Depending on the HOAs priority in relation to the first mortgage, the latter course of action would allow the HOA to sell or at least rent the property after it retakes it in foreclosure. ${ }^{117}$ However, section 523(a)(16) exposes the debtor to potential action that would allow the HOA to sue a homeowner, who is not in possession of the property, and then garnish that homeowner's wages or bank accounts, even if the association additionally pursues lien foreclosure. ${ }^{118}$

Amending section 523(a)(16) will thus tailor an HOA's available recourse without impeding on its ability to recover lost payment. It is important that the law encourages HOAs to explore alternative and more efficient courses to payment, which will also eliminate reoccurring assessments against a bankrupt debtor not in possession of the encumbered property.

The rest of this Comment will explore the available courses of action an HOA may take to recover for its lost assessments and how section 523(a)(16) should be amended to impose a lessor burden on debtors at as little a cost as possible to HOAs. This will begin with an analysis of lien priority status, a solution proffered by some legal scholars that calls for careful consideration.

\section{Is lien priority the right solution?}

It has been proposed that the solution to an HOA's priority problem, which usually subordinates an HOA lien to the first mortgage, is for HOAs to establish lien priority within their Covenants, Conditions, and Restrictions

116 See Christensen, supra note 99.

117 Jonathan M. Mofsky, Important Ruling for Associations Seeking to Foreclose in Advance of Lenders, DAILY BUS. REVIEW, http:/www.dailybusinessreview.com/home/id=1202767742325/Important-Ruling-for-Lenders/ ("By filing and quickly prosecuting separate foreclosure actions based on liens for unpaid assessments, associations have been able to acquire and rent properties embroiled in prolonged mortgage foreclosure proceedings.").

118 Jill Mazirow Eshman, What's A Homeowners' Association To Do? Collecting Dues and Assessments During Difficult Financial Times, 53 ADVOC. 33, 34 (2010) (stating "[a]t the same time as the association pursues the statutory lien foreclosure, the association may pursue a money judgment, presumably for the same limited unpaid assessments for which a statutory lien may be obtained against the nonpaying owner."). 
(CC\&Rs). ${ }^{119}$ As previously discussed, state law is one method of determining lien priority. However, because most state statutes state that an HOA lien shall relate back to the date it recorded its CC\&R, ${ }^{120}$ the HOA has the ability to establish senior priority through its CC\&R even as to a first mortgage. ${ }^{121}$ This means that the HOA could foreclose with the same rights that a bank would normally have and sell the property retaining all of the proceeds.

HOA lien priority certainly seems to be an appealing mechanism for offering HOAs better protection and the ability to find due-paying buyers that will relieve both the HOA and the previous debtor. However, this solution does not come without its drawbacks. For example, trumping the lender's lien will lead to lender's charging higher rates or refusing to lend at all to prospective buyers of property within the HOA community. ${ }^{122}$ Not only would this make it more difficult for the HOA to find due-paying buyers, it would also affect the HOAs property owners who would have more difficulty selling their property. ${ }^{123}$ For these reasons CC\&Rs will often contain a provision that any HOA lien is subordinate to a first mortgage.

Although an HOA may have strong fiscal reasons to subordinate its lien, the fact that most states permit HOAs to protect themselves through senior lien priority raises the question of whether HOAs are truly in need of section 523(a)(16) as amended. Furthermore, even without priority lien status, an HOA still has sufficient recourse as a junior lien holder to weigh against its case for keeping the discharge exception as is. With that said, the point of this Comment is not to accuse section 523(a)(16) of offering HOAs too much protection that should be curtailed to maintain bankruptcy policy. Instead, the Comment seeks to strike a better balance between the complex rights of the pertinent parties to this important property issue. The following two sections describe potential mechanisms that state and federal law could strive to promote in order to lay the groundwork for amending section 523(a)(16) as later proposed.

119 Stitzer, supra note 13, at 1431.

120 Amy Loftsgordon, Homeowners Association Super Liens, NoLO, http://www.nolo.com/legalencyclopedia/homeowners-association-super-liens.html (last visited March 24, 2017) ("The lien will typically automatically attach to that homeowner's property, commonly as of the date the HOA's Declaration of Covenants.").

121 Stitzer, supra note 13 , at 1428.

122 Id.

123 Homeowners and Condominium Associations Should Not Be Granted “Super Lien” Priority, MORTG. BANKERS ASS'N, https://www.mba.org/issues/residential-issues/hoa-super-lien-priority [hereinafter Mortgage Bankers Association] (last visited March 25, 2017). 


\section{Super liens}

The financial struggles of homeowner and condominium associations prompted calls to strengthen the associations' power to collect delinquent assessments. ${ }^{124}$ This led to many states enacting what are known as "super-lien statutes" to elevate an association's lien to a limited senior priority over the first mortgage. ${ }^{125}$ The majority of states mirror their statutory language to the Uniform Common Interest Ownership Act ("UCIOA") and the Uniform Condominium Act ("UCA"), which provide for a common assessment superlien. ${ }^{126}$ The Uniform Acts provide that an association's lien will receive seniority for six months' worth of delinquent assessments based on the association's periodic budget. ${ }^{127}$ This creates a split priority in relation to the first mortgage, which differentiates super liens from the priority liens discussed in the previous section. In his Annual Review of Banking Law, Grahame Wells states that " $[\mathrm{b}] \mathrm{y}$ giving the condo association a limited priority over the first mortgagee, the super-lien statute divides the burden of collecting long-term delinquent condo fees between the lenders and condo associations." 128 These same principles can apply to the various associations listed in section 523(a)(16).

States planning to enact super-lien statutes will have to consider the redeemability of the super-lien. Redeemability refers to whether the HOA will receive a one-time senior priority, or if the HOA can regain senior priority over all future assessment delinquencies. As Wells clarifies:

With a redeemable super-priority lien, the condo association receives a one-time senior priority for delinquent fees; once the first mortgagee pays off this senior portion, the condo association cannot return to the senior position. With a redeemable super-priority lien, the first mortgagee could, by redeeming only the priority portion of the lien upon default, receive priority over all future assessment delinquencies. The lender regains senior priority even if the amount it pays to the condo association does not discharge the entire assessment delinquency. Conversely, under a non-redeemable super-priority lien, the first mortgagee can return to senior priority only after redeeming the entire delinquent assessment. For instance, if the unit owner was in default for nine months of assessments, six months would be senior to the mortgage

124 Grahame K. Wells, The Use of Super-Liens to Promote Cooperation Between Condominium Associations and Lenders, 13 ANN. REV. BANKING L. 477, 478 (1994).

125 Id. at 484 ("Legislatures in Alaska, Colorado, Connecticut, Massachusetts, Nevada, Pennsylvania, Rhode Island, Washington, West Virginia, and the District of Columbia have enacted condominium statutes that include a super-lien provision.").

$126 I d$.

127 Id. at 490.

128 Id. at 489. 
and three months junior. If the lender paid off the six months of assessments, the remaining three months of delinquencies would then receive the senior priority. Even if the lender paid the entire nine months of delinquent fees to the condo association, future condo fee deficiencies would still receive senior priority over the first mortgage. ${ }^{129}$

Based on the existing super-lien statutes, two models are suggested: the Massachusetts model and the Uniform model. ${ }^{130}$ The Massachusetts model varies from the Uniform model's non-redeemable approach by allowing the lenders to extinguish the senior priority portion of the lien by paying off the six months of delinquent fees. Additionally, the Massachusetts model calls for attorneys' fees and a notice requirement, neither of which are included in the Uniform model.

Wells argues that inclusion of attorneys' fees will encourage lenders to cure the deficiency quickly, before an association has spent money trying to collect the assessment. ${ }^{131}$ Without such attorneys' fee provisions it is likely that an HOA would not receive a refund from the lender until the lender forecloses. Moreover, the notice provision requires HOAs to keep lenders aware of non-payments, prompting better communication between HOAs and lenders. Finally, allowing lenders to redeem their senior priority will make it easier for lenders to adequately secure HOA loans and will incentivize lenders to compensate HOAs more quickly.

\section{HOA foreclosure with junior lien status}

However, some believe that super liens lead to the same concerns that priority liens do in terms of increasing the risk of originating and servicing loans in HOA communities. ${ }^{132}$ The good news is, even with junior lien status, HOAs are not powerless to collect their assessments. At least some appellate courts have recognized an HOA's right to foreclose on delinquent assessment liens even during a lender foreclosure where the lender filed a lis pendens. ${ }^{133}$

In Florida, a recent ruling by the Fourth District Court of Appeal confirmed this. ${ }^{134}$ The case involved a prolonged mortgage foreclosure action against the homeowner, which began in $2007 .{ }^{135}$ The first mortgagee filed a

129 Id. at 492.

$130 \quad I d$.

131 Id. at 497.

132 Mortgage Bankers Association, supra note 123.

133 See Jallali v. Knightsbridge Vill. Homeowners Ass'n, Inc., 211 So. 3d 216 (Fla. Dist. Ct. App. 2017).

\footnotetext{
$134 I d$.

135 Id. at 217.
} 
notice of lis pendens, in conjunction with its foreclosure action. ${ }^{136}$ A lis pendens serves two main purposes: (1) to give notice to and thereby protect any future purchases or encumbrances of the property; and (2) to protect the plaintiff from intervening liens. ${ }^{137}$ Subsequently, the HOA recorded a lien for delinquent assessments against the homeowner and commenced its own foreclosure proceedings in 2012. ${ }^{138}$ The court found that a homeowner association's declaration of covenants, recorded not only prior to the filing of a notice of lis pendens by the first mortgagee may constitute a prior recorded interest within the meaning of the lis pendens statute. The court's reasoning was that a HOA's CC\&R constitutes an "interest" in property under section 48.23(1)(d) of Florida Statutes. ${ }^{139}$ The court then clearly states, "the filing of a lis pendens does not automatically preclude an association from foreclosing on a lien imposed under the declaration against parties other than a first mortgagee, although the association's foreclosure may be subordinate to the foreclosure of a first mortgage."

The real advantage is that once the HOA forecloses it can retake the property and collect rent on it. Although the lender's lien will remain on the property, the HOA would not be obliged to pay it since the parties are not in privity of contract. ${ }^{141}$ Naturally, the bank will want to avoid losing the property and may pay out the lien in order to avoid foreclosure. Even if the bank does not redeem the property, taking ownership away from the lender without obligation to pay the mortgage would force the lender's hand into foreclosure in order to collect on its own lien. In the meantime, the HOA might rent out the home on a short-term basis until the first mortgage holder's foreclosure is complete . In doing so the HOA would accrue monthly income and could keep the proceeds. ${ }^{142}$ In cases where the lender's claim is large and the property's value is not sufficient to induce the lender to foreclose, the HOA will have more time to collect rent. However, if the lender decides to foreclose right away, the HOA can still collect rent throughout the foreclosure process until the property is sold and a due-paying buyer moves in. In either case, the HOA is the recipient of cash flow covering the post-petition assessments, which justifies not keeping the debtor homeowner on the hook for such debt.

One drawback to junior lien foreclosure is that, in many states, an HOA would become subject to paying maintenance, taxes, and insurance on the

136 Id.

137 Id. at 218.

138 Id. at 217.

139 FLA. STAT. $\$ 48.23(1)(d)$ (2017) (stating that a notice of lis pendens does not affect a previously recorded interest or lien).

140 Jallali, 211 So. $3 \mathrm{~d}$ at 219.

141 Id.

142 Id. 
property. ${ }^{143}$ Often, HOA's are reluctant to take such responsibility at the risk that the superior lien holder forecloses before the property can be leased long enough to cover the foreclosure costs. However, these concerns do not apply in the case of a bankrupt homeowner. When an HOA forecloses against an insolvent homeowner, the HOA would prefer a quick foreclosure process that places a new due-paying member on the property. However, in the event of a delayed foreclosure, the HOA can take comfort in its ability to collect rent until a new member purchases the home from the bank. ${ }^{144}$ Meanwhile, the bankrupt homeowner is relieved from its assessment obligations and can enjoy a fresh start.

4. Changes required in state law to facilitate efficient assessment lien foreclosure

Because this Comment urges an amendment to the federal Bankruptcy Code, rationalized upon the view that assessment lien foreclosure offers HOAs a sufficient course to payment, the Comment must also urge uniformity across state laws that will allow all HOAs to recover equally. This is currently not the case because the foreclosure process varies from state to state. Therefore, HOAs in one state may be entitled to quick and inexpensive foreclosure proceedings, while an HOA in another state may incur attorneys' fees that exceed the amount of default assessments.

Admittedly, one problem with suggesting foreclosure as a mechanism for recovering default assessments is that the foreclosure process can be quite expensive, especially if judicial foreclosure is required under state law. For example, Florida and nineteen other states require judicial foreclosure. ${ }^{145}$ This process was illustrated in the above-captioned case, Jallali, where the association had to bring an action against the property owner in order to foreclose on its assessment lien. ${ }^{146}$ Judicial foreclosure requires the creditor to file a lawsuit in state court and typically takes several months, or even years to complete. ${ }^{147}$

143 Gerri Detweiler, Property Taxes After Foreclosure: Who Pays?, AOL (August 7, 2013, 2:00 PM), https://www.aol.com/article/2013/08/07/property-taxes-after-foreclosure-who-pays/20689156/ ("The liability follows the property, not the owner.").

144 Collecting HOA Assessments from Banks, HOALEADER, https://www.hoaleader.com/public/Collecting-HOA-Assessments-from-Banks-Discussion-Forum-Followup.cfm (last visited March 25, 2017) ("[T]he HOA forecloses on its lien, rents out the home, and keeps the proceeds in a separate account.").

145 Foreclosure Laws and Procedures By State, REALTYTRAC, http://www.realtytrac.com/realestate-guides/foreclosure-laws/ (last visited March 25, 2017).

146 Jallali, 211 So. $3 \mathrm{~d}$ at 217.

147 Amy Loftsgordon, What is Judicial Foreclosure?, ALLLAw, http://www.alllaw.com/articles/nolo/foreclosure/judicial-foreclosure.html (last visited March 25, 2017). 
In order to judicially foreclose an assessment lien, an HOA must file a lawsuit against the delinquent homeowner and obtain a judgment against such homeowner that: (1) establishes the amount owed to the HOA; and (2) orders the HOA's assessment lien be foreclosed on such homeowner's property to satisfy the amount awarded to the HOA that is found to be secured by its assessment lien. ${ }^{148}$ This is a very timely and costly process. ${ }^{149}$ A lawsuit, if contested, can take more than a year to go to trial, notwithstanding a possible appeal. ${ }^{150}$ Therefore, the attorneys' fees incurred can be significant. Even if the court awards to the HOA all of the attorneys' fees, it is possible that the foreclosure proceeds cover the added fees. ${ }^{151}$

Although a judicial foreclosure offers the advantage of being able to create a "judgment lien," this type of lien is not worth much to an HOA foreclosing against an insolvent debtor. Therefore, non-judicial foreclosure may be a more attractive option in the type of situation discussed in this Comment. Non-judicial foreclosure is faster and less expensive than its judicial counterpart. In a non-judicial foreclosure the HOA or appointed trustee would first provide notice of default with a limited time to cure. ${ }^{152}$ Upon failure to cure, a foreclosure sale will be set and the HOA or trustee will commence to prepare a notice of sale. ${ }^{153}$ The notice of sale gives the date, time, and location of the foreclosure sale and is typically recorded in county records, mailed to the homeowner, and published in newspapers. ${ }^{154}$ It is at the actual foreclosure sale where the property may revert back to the foreclosing party if not sold to a third-party. ${ }^{155}$ The disadvantage of conducting a non-judicial foreclosure is that it may possibly subject the HOA to a wrongful foreclosure lawsuit if not properly conducted. ${ }^{156}$ However, if properly conducted the non-judicial foreclosure can save the HOA a lot of time and money.

The majority of states allow lenders to choose between judicial and nonjudicial foreclosure proceedings. ${ }^{157}$ However, this is not the case for the nearly twenty states that require judicial foreclosure. Therefore, the minority of states should consider adopting a non-judicial foreclosure option for

148 GREGORY S. CAGLE, HOA ASSESSMENT LIENS 13 (2010), https://ssjmlaw.com/wp-content/uploads/2012/05/2010-Advanced-Real-Estate-Law-Article-HOA-Assessment-Lien-Foreclosure.pdf

149 Id. at 14

150 Id.

151 Id.

152 Amy Loftsgordon, What is Nonjudicial Foreclosure?, ALLLAw, http://www.alllaw.com/articles/nolo/foreclosure/nonjudicial-foreclosure.html (last visited March 25, 2014).

$153 I d$

$154 I d$

155 Id.

156 CAGLE, supra note 148.

157 Foreclosure Laws and Procedures By State, supra note 145. 
HOAs, including condominium associations, and any other entity that may be affected by an amendment to section 523(a)(16). This means that legislation pertaining to the HOA foreclosure process shall authorize HOAs to foreclose their assessment liens by non-judicial foreclosure if expressly authorized to do so by their CC\&R or by state law.

\section{Justifying an Amendment to Section 523(a)(16)}

At this point, the Comment has described, in depth, some of the false assumptions that the 2005 amendment to section 523(a)(16) were based on. One assumption proven false is that the foreclosure process is not often delayed. Statistics reveal that lender foreclosures can take years, ${ }^{158}$ and are often intentionally delayed by lenders lying in wait for an increase in property values. ${ }^{159}$ Another assumption challenged throughout is that protecting an HOA's interests requires keeping the debtor on the hook for post-petition assessments. However, the Comment has so far explored a number of ways an HOA may prioritize its lien and recover losses without pursuing legal action against an insolvent debtor. Now the Comment must address its proposed amendment for section 523(a)(16) of the federal Bankruptcy Code.

The first goal of the amendment must be to incentivize lenders to promptly foreclose or take possession rather than indefinitely remaining idle while the debtor or HOA bear expenses that directly inure to the lender's benefit. Presently, section 523(a)(16) imposes accruing debt solely upon the debtor without considering how to leverage the interests of other parties with rights in the property to better serve bankruptcy's "fresh start" policy. In regards to this inequitable benefit one court states:

The bank is the unintended beneficiary of the perfect storm of natural disaster and this legislative inequity. While the HOA fees continue to accrue against the debtor the bank is de-incentivized to take any action. The economics of the situation allow the bank to sit idle and not foreclose as long as the debtor, not the bank is liable for the HOA fees. As both [the association] and the Bank admitted the Bank receives the benefit of the HOA services such as landscaping improvements, common area maintenance, signage, and security. Meanwhile the debtor who does not even live in the flooded condominium and has tried valiantly to handle her financial crises caused by the flood receives minimal if any benefit for fees she must pay. ${ }^{160}$

158 See Loftsgordon, Foreclosure Timelines, supra note 4.

159 Adams, supra note 7, at 349 ("'With the real estate collapse, lenders, who otherwise have the right to do so, are choosing not to foreclose on their collateral[,] leaving homeowners in limbo."') (quoting In re Pigg, 453 B.R. 728, 733 (Bankr. M.D. Tenn. 2011)).

160 In re Pigg, 453 B.R. at 732 n.5. 
The first step to incentivizing lenders to promptly foreclose is to amend section 523(a)(16). The 1994 version aimed to prevent freeriding members but left HOAs to otherwise pick up the slack. The 2005 version aimed to better protect creditors but instead created freeriding lenders and did not accomplish what it intended to in terms of securing payment for HOAs. Therefore, there has not yet been a version of this section that has struck an equitable balance between the debtor-member's right to a fresh start, the HOA's right to payment of its assessments and fees, and the lender's right to wait for an advantageous market.

Of course, the reality is that simply allowing full discharge of a homeowner's HOA debts will not serve HOAs well. Ideally, completely discharging the debtor's HOA fees and assessments would incentivize lenders to promptly foreclose or take possession to ensure that the HOA receives what it needs to maintain the property so the lender can optimize its return. However, in practice, lenders receive the benefit of HOA expenditures without assuming any collection costs. Regardless of delinquent payments and foreclosure proceedings, HOAs continue to expend funds to upkeep the property's value, which increases the value of the property in a foreclosure sale. ${ }^{161}$ Ultimately, lenders are not legally responsible for dues owed by their borrowers and often refuse to refund any of these costs from its proceeds in a foreclosure sale, compounding the inequity. ${ }^{162}$ However, as discussed, the emergence of state super-lien statutes will help restore equity between HOAs and lenders, reducing the need to enforce delinquent fees against the debtor homeowner to a point that justifies an amendment to section 523(a)(16).

\section{Proposed Amendment to Section 523(a)(16)}

Some would argue that section 523(a)(16) should be completely removed from the Code's discharge exceptions. ${ }^{163}$ The premise behind this argument is that Congress is substantially expanding discharge exceptions to include debts where no culpable conduct is required, and where compelling public policy concerns are not apparent. ${ }^{164}$ Pertaining to section 523(a)(16) these critics suggest that expansion of nondischargeability to include HOA fees, absent the showing of wrongful conduct, is a major change in bankruptcy policy to benefit a special interest group that will erode the bankruptcy's "fresh start" policy. ${ }^{165}$

161 Wells, supra note 124 , at 478.

$162 I d$.

163 Miles, supra note 9, at 804.

$164 I d$. at 803.

165 Id. at 803 n.42. 
Although it is true that simply not paying a creditor does not rise to the level of misconduct that the Code originally set out to except from discharge, being a freeriding member at the expense of other HOA members might. This is to say that there are strong policy reasons for allowing some aspects of section 523(a)(16) to remain part of the Code. For example, beyond offering protection to HOAs, section 523(a)(16) also exists to protect members of the HOA community and their property values. Allowing an individual to benefit from personal and communal property without paying his or her personal dues is not something that the association, or its members, should have to tolerate, and this is what the 1994 provision sought to prevent. Therefore, section 523(a)(16) should exist only to prevent the freeriding member and should not apply to those who do not continue to possess or financially benefit from the property after bankruptcy.

This Comment's proposed provision would read similarly to the 1994 provision in all aspects except for the addition of language clarifying that homeowners associations are included within the exception. Here is the amendment as proposed:

A discharge under section $727,1141,1228(a), 1228(b)$, or 1328 (b) of this title does not discharge an individual debtor from any debt ... for a fee or assessment that becomes due and payable after the order for relief to a membership association with respect to the debtor's interest in a dwelling unit that has condominium ownership, in a share of a cooperative housing corporation, or a lot in a homeowner's association, but only if such fee or assessment is payable for a period during which-

(A) the debtor physically occupied a dwelling unit in the condominium or cooperative project; or

(B) the debtor rented the dwelling unit to a tenant and received payments from the tenant for such period, but nothing in this paragraph shall except from discharge the debt of a debtor for a membership association fee or pending or subsequent bankruptcy case. ${ }^{166}$

The purpose of this proposal is to relieve the burden of accruing assessments from non freeriding members while keeping debtors who continue to use their property for personal use or for generating rental income responsible for assessments coming due after filing. ${ }^{167}$

166 Compare 11 U.S.C. § 523(a)(16) (1994), with 11 U.S.C.A. § 523(a)(16) (West 2017).

167 Id. 
Considering the purpose of section 523 discharge exceptions, which is to hold debtors responsible for their debts pertaining to personal misconduct or an important policy issue, Congress should be able to articulate, with specificity, which category the discharge exception pertains to and why. Although protecting the interests of HOAs is important, Congress may find itself bending to the demands of every group of creditors if it is not careful to draw a line between public policy and creditor protection. In this case, public policy should not tolerate freeriding members. However, burdening non-freeriding debtors to the extent section 523(a)(16) does, solely pertains to creditor protection. Certain creditors may be entitled to additional protection, but in light of bankruptcy policy, this should not be liberally granted. ${ }^{168}$ Because an HOA has the ability to prioritize its lien, foreclose on its assessments, and collect rent on the property, there simply is not a compelling justification for extending protection beyond what is required to serve the policy interests.

\section{E. The Surviving Lien}

A discharge in bankruptcy extinguishes only one mode of enforcing a claim - namely, an action against the debtor in personam - while leaving intact another - namely, an action against the debtor in rem. ${ }^{169}$ This means that any assessment lien placed on the homeowner's property prior to the owner's subsequent bankruptcy will survive the bankruptcy and not alter the HOA's in rem rights. It also means that a lien can be placed on the property even if an in personam claim against the debtor is discharged through bankruptcy.

The Code's treatment of liens further suggests that section 523(a)(16) does not strike a fair balance between protecting creditor's rights while providing the debtor a fresh start. Essentially, section 523(a)(16) proffers the creditor two causes of action, allowing both causes their full force and effect. Therefore, the proposed amendment stands to better balance the dual purposes of bankruptcy by allowing creditors to keep both rights of action against freeriding members and discharging an in personam action against a non-freeriding debtor. Even those who argue that bankruptcy discourages people from paying their debts and should be limited to those in extreme

168 Local Loan Co. v. Hunt, 292 U.S. 234, 244 (1934) (stating that the purpose of the bankruptcy code is to provide the honest debtor a fresh start, unhampered by the pressure and discouragement of preexisting debt).

169 See City of Richmond v. Bird, 249 U.S. 174, 177 (1919) ("Section 67 d . . . declares that liens given or accepted in good faith and not in contemplation of or in fraud upon this act, shall not be affected by it.”); see also Johnson v. Home State Bank, 501 U.S. 78, 84 (1991). 
difficulty, ${ }^{170}$ would likely conclude that a debtor forced to abandon its home has fallen upon extremely difficult times.

However, the adage that "liens pass through bankruptcy unaffected" may not always be reliable. ${ }^{171}$ Section 1141 (c) of the Code states:

Except as provided in subsections (d)(2) and (d)(3) of this section and except as otherwise provided in the plan or in the order confirming the plan, after confirmation of a plan, the property dealt with by the plan is free and clear of all claims and interests of creditors, equity security holders, and of general partners in the debtor. ${ }^{172}$

The Seventh Circuit determined that unless the lien is expressly preserved by the terms of the Plan of Reorganization the lien is voided by the confirmation of that Plan. ${ }^{173}$ The court limited the decision to situations where the secured creditor "participates in the reorganization," otherwise section 1141(c) would not apply. ${ }^{174}$ Moreover, the holding of In re Penrod is expressly limited to situations where a secured creditor has participated in a Chapter 11 plan of reorganization, and the plan does not specifically provide for the preservation of the creditor's lien. ${ }^{175}$ However, let this serve as a warning to HOAs participating in a debtor's Chapter 11 plan. Although Chapter 11 cases are normally filed by businesses rather than individuals, an individual debtor may still choose to reorganize its debts in an effort to restructure its finances and protect its assets. Therefore, in order to retain the assessment lien after bankruptcy, it might be necessary to expressly include the lien as part of the debtors plan, at least according to the Seventh Circuit.

\section{CONCLUSION}

The take away from this Comment is that the Bankruptcy Code should strive to balance the interests of both creditors and debtors. Presently, section 523(a)(16) tips the balance in favor of HOA creditors at the expense of debtor-members who no longer possess the property or benefit from it. The reason it is difficult to justify the expansion of this creditor protection is that there are already reliable mechanisms that can be used to help HOAs receive payment of their assessments and prompt banks to foreclose such as first

170 Beth A. Buchanan Staudenmaier, Survival of Liens: "Liens Pass Through Bankruptcy Unaffected”-Or Do They? 21 U. DAYTON L. REV. 445, 461 (1996).

171 See In re Penrod, 50 F.3d 459 (7th Cir. 1995).

17211 U.S.C.A. $\S 1141$ (c) (West 2017).

173 In re Penrod, 50 F.3d at 463.

174 Id.

175 Id. at 462-64. 
priority status, super-lien status, HOA assessment lien foreclosure, and the surviving lien. However, lobbyists successfully convinced Congress that the only way HOAs could maintain their community would be by ensuring that someone was on the hook for the unpaid assessments and, as the legal owner of the property, the debtor-member was the easy target. However, the decision to create this discharge exception neglected the heavy burdens that are placed on the debtor and the paths to repayment available to HOAs.

The Comment also seeks to remind Congress, as well as those contemplating these issues, that the "fresh start" policy was not solely intended as a gift to debtors at the expense of creditors. Although the policy enables debtors to once again become a productive member of society, and relieves them of the hopelessness associated with the burden of excessive debt, the policy also serves economic purposes. A fresh start reduces the administrative costs of bankruptcy by incentivizing the debtor to cooperate in the debtor's distribution of assets. Furthermore, the fresh start encourages economic activity by shifting resources to their most productive use and by eliminating some of the risks of business failure.

Therefore, Congress should revert section 523(a)(16) to its original form and include homeowners associations in the list of creditors to avoid the same confusion that resulted in 1994. Congress must recognize that super-lien status and HOA assessment lien foreclosure are better methods of collecting payment for default assessments than relying on an insolvent debtor to make these payments. Because these mechanisms exist, section 523(a)(16) offers excessive creditor protection that should be curtailed. Under the proposed approach, the non-freeriding debtor would be freed from accumulating HOA debt, the HOA would receive a due paying member or tenant quicker, and lenders would retain their priority lien status.

Even if Congress chooses not to support super liens, an HOAs ability to foreclose on its lien and hold title until the first lien holder forecloses is a boon for the HOA. Possessory rights will allow the HOA to receive rent on the property in the short-term while the lender goes through its own foreclosure process. If the lender has ownership rights but does not take possession of the property, the lender may choose to redeem the property during the HOA foreclosure. In this case the lender would have to pay whatever is owed to the association. Therefore, regardless of how the lender decides to act, the HOA has the ability to produce income on the property to cover, and perhaps exceed, the debtor-members default assessments. Because of the surviving lien, the HOA need not be concerned that their in rem rights will be extinguished along with the debtors prepetition debt. Thus, an HOA lien foreclosure covers both prepetition and post-petition assessments, allowing the HOA to cover all loss. 
Ultimately, these mechanisms question the logic of leaving a debtor homeowner on the hook for accumulating assessments for as long as it takes their mortgagee to foreclose, which often takes years. Excepting these debts from discharge would be squarely aligned with Bankruptcy's fresh start policy and would better balances the goals of bankruptcy: creditor protection and a fresh start for debtors. 